\title{
Nanostructured lanthanum manganate composite cathode
}

Wang, Wei Guo; Liu, Yi-Lin; Barfod, Rasmus; Schougaard, Steen Brian; Gordes, Petru; Ramousse, Severine; Hendriksen, Peter Vang; Mogensen, Mogens Bjerg

\section{Published in:}

Electrochemical and Solid-State Letters

Link to article, DOI:

$10.1149 / 1.2081890$

Publication date:

2005

Document Version

Publisher's PDF, also known as Version of record

Link back to DTU Orbit

Citation $(A P A)$ :

Wang, W. G., Liu, Y-L., Barfod, R., Schougaard, S. B., Gordes, P., Ramousse, S., Hendriksen, P. V., \& Mogensen, M. B. (2005). Nanostructured lanthanum manganate composite cathode. Electrochemical and SolidState Letters, 8(12), A619-A621. https://doi.org/10.1149/1.2081890

\section{General rights}

Copyright and moral rights for the publications made accessible in the public portal are retained by the authors and/or other copyright owners and it is a condition of accessing publications that users recognise and abide by the legal requirements associated with these rights.

- Users may download and print one copy of any publication from the public portal for the purpose of private study or research.

- You may not further distribute the material or use it for any profit-making activity or commercial gain

- You may freely distribute the URL identifying the publication in the public portal 
${ }^{a}$ Department of Materials Research, Ris $\phi$ National Laboratory, DK-4000 Roskilde, Denmark

${ }^{b}$ Topsoe Fuel Cell A/S, Material and Stack Development, DK-2800 Lyngby, Denmark

\begin{abstract}
Anode-supported cells were fabricated with optimized cathodes showing high power density of $1.2 \mathrm{~W} / \mathrm{cm}^{2}$ at $800^{\circ} \mathrm{C}$ under a cell voltage of $0.7 \mathrm{~V}$ and an active area of $4 \times 4 \mathrm{~cm}$. A microstructure study was performed on such cell using a field-emission gun scanning electron microscope, which revealed that the $\left(\mathrm{La}_{1-x} \mathrm{Sr}_{x}\right)_{y} \mathrm{MnO}_{3+\delta}$ (LSM) composite cathodes consist of a network of homogenously distributed LSM, yttria-stabilized zirconia (YSZ), and pores. The individual grain size of LSM or YSZ is approximately $100 \mathrm{~nm}$. The degree of contact between cathode and electrolyte is $39 \%$ on average.

(C) 2005 The Electrochemical Society. [DOI: 10.1149/1.2081890] All rights reserved.
\end{abstract}

Manuscript submitted June 14, 2005; revised manuscript received August 10, 2005. Available electronically October 7, 2005.

Planar anode-supported cells have shown power density of more than $1 \mathrm{~W} / \mathrm{cm}^{2}$ at $800^{\circ} \mathrm{C}$ under $0.7 \mathrm{~V} .^{1-5}$ This led to a reduction of operation temperature from 1000 to $750^{\circ} \mathrm{C}$ in solid oxide fuel cell (SOFC) systems, which has resulted in a significant cost reduction and improvement of the long-term stability. Such successes have been realized by the cell design as (LSM + YSZ)/YSZ/(Ni + YSZ) using state of art materials, namely, yttria-stabilized zirconia (YSZ) for the electrolyte, Ni + YSZ for the anode, and $\left(\mathrm{La}_{1-x} \mathrm{Sr}_{x}\right)_{y} \mathrm{MnO}_{3 \pm \delta}(\mathrm{LSM})+\mathrm{YSZ}$ as the cathode. This design is by far the most commonly used. The theoretical and experimental work has shown that the dominant loss was attributed to the cathode in the cell operating at the range of $600-850^{\circ} \mathrm{C}$. To reduce the polarization resistance in the cathode, many groups have studied the relationship between the cathode microstructure and the electrochemical properties. $^{6-10}$ They indicated that a composite cathode with desirable microstructure was the key to obtaining good electric and chemical performance of the cathode. In the composite cathode with LSM and YSZ, the electrochemical reduction of oxygen occurs at the conjunction of the three-phase boundary (TPB). The three phases are LSM, YSZ, and gas (pores). In a fuel cell using composite cathode, the TPBs extend well into the cathode in areas placed away from the physically distinct cathode/electrolyte interface, and substantially lower the cathodic polarization. Therefore not only the microstructure at the cathode/electrolyte interface, but also the entire cathode microstructure was considered to be responsible for the polarization of the cathode. Recently, Williford and Singh reported their computational design analysis of a high performance cathode. ${ }^{11}$ Their calculation illustrated that an optimal cathode structure may be built by a two-layer structure with a thinner layer with smaller grain diameters at the cathode/electrolyte interface followed by a relatively thicker outer layer with larger grains at the electrode/ oxidant interface. However, this report was lacking detailed microstructure information and a clear relation between performance and microstructure. Moreover, little microstructure information was reported in the cells with high power densities. At Ris $\varnothing$ National Laboratory, the processing optimization of the LSM/YSZ composite cathode was carried out in a systematic way, ${ }^{5}$ which led to doubled power density enhancement in comparison with cells from a previous version. In this work, the properties of the high power density cell are reported and the cathode microstructure is investigated using a high resolution field-emission gun scanning electron microscope (FEGSEM).

\section{Experimental}

Anode-supported cells were produced by tape casting the anode support, spraying the NiO-YSZ active anode and the YSZ electro-

\footnotetext{
* Electrochemical Society Active Member

${ }^{\mathrm{z}}$ E-mail: wei.guo.wang@risoe.dk
}

lyte layer, followed by cosintering. Then the cathode was sprayed and sintered. ${ }^{5}$ The cells with an active electrode area of $4 \times 4 \mathrm{~cm}$ were tested in a setup designed at Ris $\varnothing .{ }^{12}$ Humidified hydrogen with $5 \%$ water was used as the fuel and air was used as the oxidant. Current loads up to $40 \mathrm{~A}$ were applied to the cell to obtain the current-voltage (I-V) measurements. The cell tests were performed in a temperature range from 850 to $650^{\circ} \mathrm{C}$. The FEGSEM ZEISS Supera-35 used in this work has a superb image resolution, namely, $1.0 \mathrm{~nm}$ at $20 \mathrm{kV}$ and $2.5 \mathrm{~nm}$ at $1 \mathrm{kV}$ in theory.

\section{Results and Discussion}

Figure 1 shows the I-V curves of an anode-supported cell produced using the improved cathode processing technique. The cells with an active area of $4 \times 4 \mathrm{~cm}$ were tested using humidified hydrogen with $5 \% \mathrm{H}_{2} \mathrm{O}$ as fuel and air as oxidant. The hydrogen flow was $30 \mathrm{~L} / \mathrm{h}$ and airflow was either 140 or $170 \mathrm{~L} / \mathrm{h}$. Figure $2 \mathrm{dem}-$ onstrates the high power density achieved in the anode-supported cell using the optimized cathode.

Table I summarizes the performance of the anode-supported cell Here the $T_{\text {imax }}$ is the measured cell temperature at maximum current. The ASR is the area specific resistance of the anode-supported cell $\left[A S R=(O C V-V) / i_{\max }\right.$, where OCV is the open-circuit voltage, $V$ is the cell voltage, and $i_{\max }$ is the maximum current density]. Almost theoretical open cell voltages were obtained indicating tight electrolyte, optimal electrical potential through the cell, and tight cell test house. Power density as high as 1.2 and $0.5 \mathrm{~W} / \mathrm{cm}^{2}$ at 800 and $700^{\circ} \mathrm{C}$, respectively, have been achieved under a voltage of $0.7 \mathrm{~V}$. The fuel utilization (F.U.) at $0.7 \mathrm{~V}$ is also shown in Table I. This

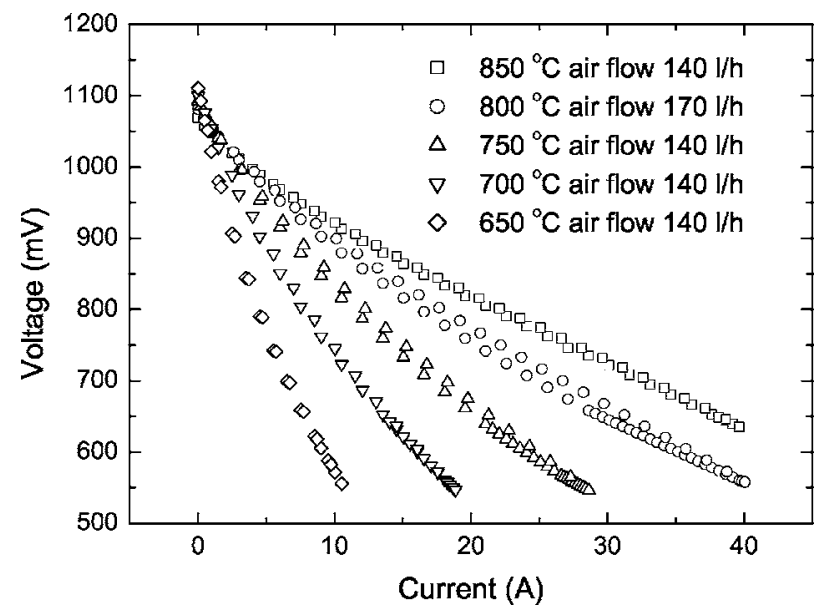

Figure 1. I-V curves obtained under a hydrogen flow of $30 \mathrm{~L} / \mathrm{h}$ with $5 \%$ water vapor. 


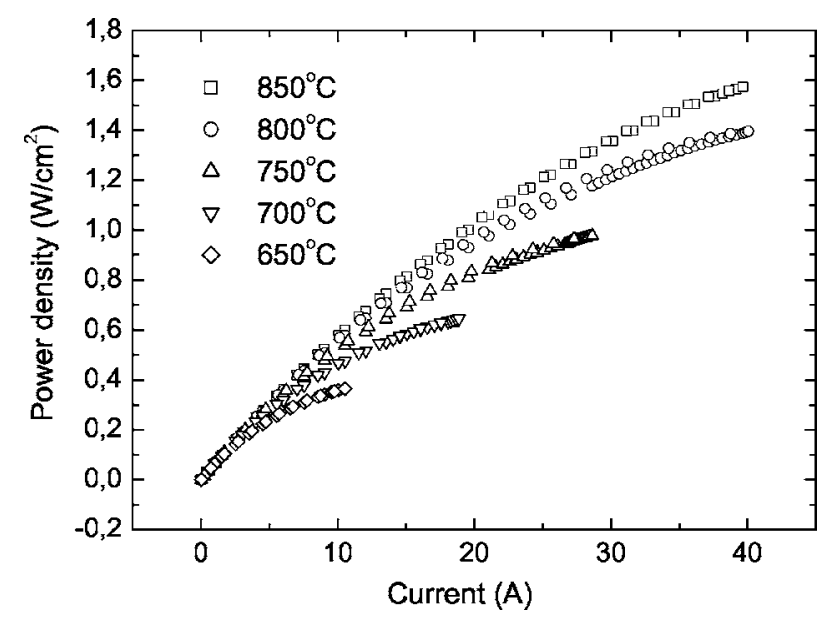

Figure 2. Power density obtained in the anode-supported cell $(4 \times 4 \mathrm{~cm}$ active area).

performance indicates that the anode-supported cell with improved LSM/YSZ composite cathode has the potential to be operated at $650-750^{\circ} \mathrm{C}$ with an acceptable power density.

The polished cross section of the cell was examined in the FEGSEM ZEISS Supra-35 with focus on the cathode and the cathode/electrolyte interface. Figure 3 is a micrograph obtained by the backscattered detector. Figure 4 was obtained using the high efficiency inlens detector and a very low accelerating voltage. It is a high-resolution image of the polished sample surface. As this image is free of the influence of the depth under the surface, it is excellent for evaluating the adhesion at the interface.

The cathode was a very fine structured composite with uniformly distributed LSM/YSZ and pores. The LSM and YSZ were sintered together forming a network, and it was incorporated uniformly with a network of pores. Because the backscattered coefficients of LSM and YSZ are very close to each other, the two phases cannot be distinguished clearly in Fig. 3. However, energy dispersive spectrometry (EDS) mapping shows that the distribution of the LSM and YSZ grains are homogeneous. Furthermore, a distinct feature of this cathode is that the LSM/YSZ network is well adhered to the electrolyte as shown in Fig. 4. It can be seen that almost all the available "branches" of the LSM/YSZ network at the interfacial region are connected to the electrolyte.

To quantify the degree of interface adhesion, the linear coverage of the electrolyte interface by the cathode phases, i.e., the length fraction of the "connecting bridges," is measured on 3 inlens images. The measured coverage value varied from 32 to $52 \%$ with an average value of $39 \%$, shown in Table II. The width of each bridge was measured as well, the average value of which was $62 \mathrm{~nm}$. The YSZ network in the composite cathode is expected to grow like a tree with strong roots. Such connected network offers large extended

\begin{tabular}{|c|c|c|c|c|c|c|}
\hline $\begin{array}{l}\text { Temperature } \\
\left({ }^{\circ} \mathrm{C}\right)\end{array}$ & $\begin{array}{l}T_{\operatorname{imax}} \\
\left({ }^{\circ} \mathrm{C}\right)\end{array}$ & $\begin{array}{c}\mathrm{OCV} \\
(\mathrm{V})\end{array}$ & $\begin{array}{c}\text { Current at } \\
0.7 \mathrm{~V} \\
\text { (A) }\end{array}$ & $\begin{array}{c}\text { Power } \\
\text { density at } \\
0.7 \mathrm{~V} \\
\left(W / \mathrm{cm}^{2}\right)\end{array}$ & $\begin{array}{c}\text { ASR } \\
\left(\Omega \mathrm{cm}^{2}\right)\end{array}$ & $\begin{array}{l}\text { F.U. } \\
(\%)\end{array}$ \\
\hline 850 & 864 & 1.070 & 32.9 & 1.44 & 0.175 & 46 \\
\hline 800 & 816 & 1.082 & 26.7 & 1.17 & 0.209 & 35 \\
\hline 750 & 758 & 1.092 & 18.3 & 0.8 & 0.305 & 22 \\
\hline 700 & 708 & 1.101 & 11.7 & 0.51 & 0.47 & 16 \\
\hline 650 & 655 & 1.111 & 6.6 & 0.29 & 0.845 & 9 \\
\hline
\end{tabular}

${ }^{\mathrm{a}}$ Fuel utilization at $0.7 \mathrm{~V}$.

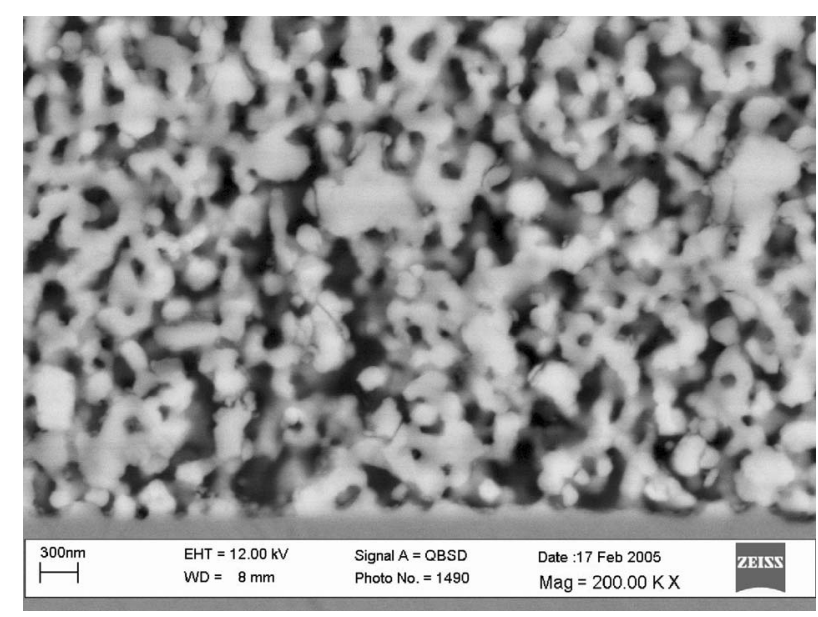

Figure 3. A backscatter image of the cathode and cathode/electrolyte interface.

contacts between ionic conductor electrolyte YSZ and electronic conductor LSM. Porous structure with very small grain size enlarges the number of the active TPBs. However, such beneficial effect can be realized only when the adhesion between electrolyte and cathode is strong, namely, the roots are strong.

Figure 5 shows a fractured cross section of a symmetrical cathode cell in a configuration of (LSM + YSZ)/YSZ/(LSM + YSZ). The fabrication method of the cathode in the full cell reported in this work was implemented from the parameters found in the optimization of processing with a series of symmetrical cathode samples. It was expected that identical processing conditions be applied to the preparation of the cathodes in the samples shown in Fig. 5 and 3. From Fig. 5, the individual grains either LSM or YSZ are clear and round. The grain size is approximately of $100 \mathrm{~nm}$. Sintering necks between the grains indicate good connection between LSM/LSM, LSM/YSZ, or YSZ/YSZ grains. High numbers of active TPB is expected in such cathode network under the condition of strong adhesion at the cathode/electrolyte interface shown in Fig. 4 and Table II. In this picture, it was expected that the cross section was the weakest one because of the fracture nature of the broken sample.

We have demonstrated that a nanostractured cathode can be produced in the SOFC processing condition, namely, at high temperature. Our long-term performance evaluation and post-test analysis indicated the nanostructure was kept in the SOFC operation
conditions.

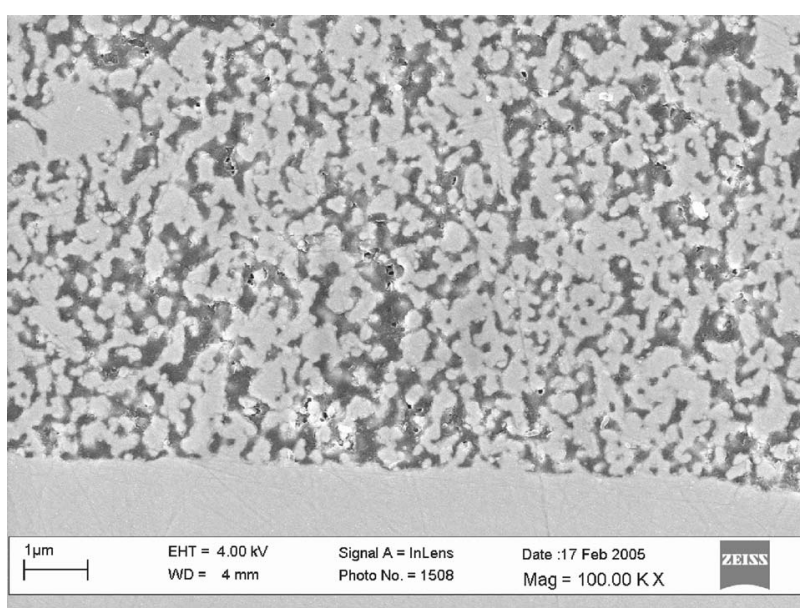

Figure 4. A secondary electron image obtained using the inlens detector on the cathode/electrolyte interface. 


Table II. Length fraction of the connecting bridge between
LSM + YSZ and YSZ.
\begin{tabular}{lcccc} 
Cell name & Bridge min & Bridge max & Average & $\begin{array}{c}\text { Average size of } \\
\text { the bridge }\end{array}$ \\
\hline C0631 & $32 \%$ & $52 \%$ & $39 \%$ & $62 \mathrm{~nm}$
\end{tabular}

It's difficult to draw the direct conclusion that smaller grain size leads to larger number of active TPBs and lower cathode polarization. ${ }^{9}$ From many studies done in the past, it is clear that the electrode performance, which was ultimately evaluated by the area specific resistance, is determined by multimicrostructure factors, including grain size, pore size, electrolyte/electrode interface, electrode uniformity, as well as the distribution of the network. Theoretical calculation has shown that doubled current may be obtained by reducing the grain size from 1.0 to $0.25 \mu \mathrm{m} .{ }^{11}$ It is also straightforward that smaller grain and pore size lead to larger number of active TPBs. However, such a hypothesis may be established only under the condition of well and homogeneously connected ionic, electronic components and pores in the cathode as well as good adhesion at electrolyte/electrode. This work has demonstrated that high power density can be achieved by the nanostructured cathode.

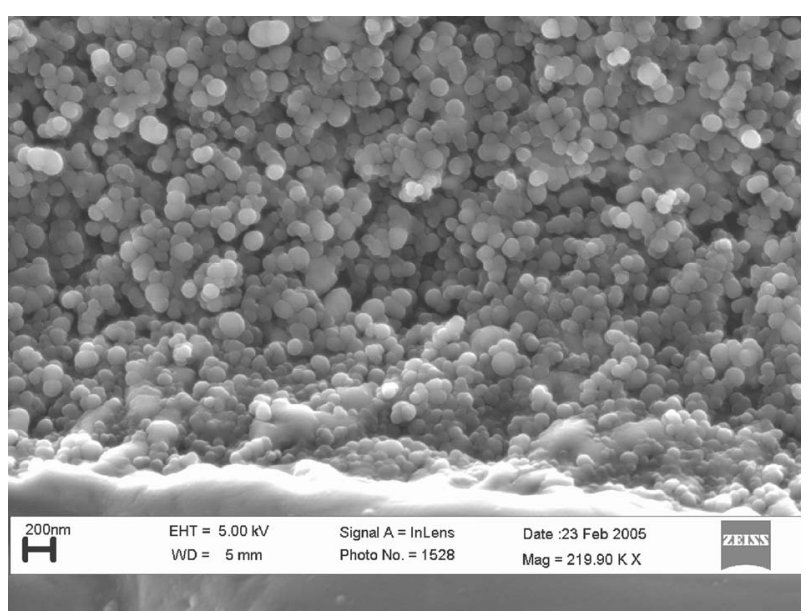

Figure 5. Fractured cross section of a symmetrical cathode cell.

\section{Conclusion}

By FEGSEM ZEISS Supera-35, a microstructure analysis was conducted on the cathode of a high power density fuel cell. The microstructure of the composite cathode shows a homogeneous porous network consisting of three components LSM, YSZ, and pores. The individual grain size of either LSM or YSZ was approximately $100 \mathrm{~nm}$. The interface at cathode and electrolyte is well bonded. The percentage of contact line at cathode/electrolyte interface was measured to be $39 \%$ on average. By engineering the cathode through processing optimization, it was possible to make nanostructured cathodes, which are believed to increase the length of the active $\mathrm{TPB}$, thereby enhancing the power density of the cell.

\section{Acknowledgments}

This work was performed as a part of the Danish SOFC program DK-SOFC, which was supported by the Danish Energy Agency. Colleagues at Ris $\emptyset$ National Laboratory are acknowledged for assistance in the sample preparation and testing.

Ris $\phi$ National Laboratory assisted in meeting the publication costs of this article.

\section{References}

1. S. Souza, S. J. Visco, and L. C. De Jonghe, J. Electrochem. Soc., 144, L35 (1997) 2. J.-W. Kim, A. V. Virkar, K.-Z. Fung, K. Mehta, and S. C. Singhal, J. Electrochem Soc., 146, 69 (1999).

3. E. Tang, F. Martell, B. Brule, B. Borglum, and D. Ghosh, in Proceedings of Fifth European SOFC Forum, J. Huijsmans, Editor, V1, p. 26 (2002).

4. N. Minh, in Solid Oxide Fuel Cells VIII, S. C. Singhal and M. Dokiya, Editors, PV 2003-07, p. 43, The Electrochemical Society Proceedings Series, Pennington, NJ (2003)

5. W. G. Wang, R. Barfod, P. H. Larsen, K. Kammer, J. J. Bentzen, P. V. Hendriksen, M. Mogensen, in Solid Oxide Fuel Cells VIII, S. C. Singhal and M. Dokiya, Editors, PV 2003-07, p. 400, The Electrochemical Society Proceedings Series, Pennington, NJ (2003)

6. T. Kenjo and M. Nishiya, Solid State Ionics, 57, 295 (1992).

7. M. J. L. Østergård, C. Clausen, C. Bagger, and M. Mogensen, Electrochim. Acta, 40, 1971 (1995).

8. K. Sasaki, J.-P. Wurth, R. Gschwend, M. Gödickemeier, and L. J. Gauckler, J. Electrochem. Soc., 143, 530 (1996).

9. F. H. van Heuveln, H. J. M. Bouwmeester, and F. P. F. van Berkel, J. Electrochem Soc., 144, 126 (1997).

10. M. J. Jørgensen, S. Primdahl, C. Bagger, and M. Mogensen, Solid State Ionics, 139, 1 (2001).

11. R. E. Williford and P. Singh, J. Power Sources, 128, 45 (2004)

12. R. Barfod, S. Koch, Y.-L. Liu, P. H. Larsen, and P. V. Hendriksen, Solid Oxide Fuel Cells VIII, S. C. Singhal and M. Dokiya, Editors, PV 2003-07, p. 1158, The Electrochemical Society Proceedings Series, Pennington, NJ (2003).

13. R. Barford, M. Mogensen, T. Klemensø, A. Hagen, Y.-L. Liu, and P. V. Hendriksen, Solid Oxide Fuel Cells IX, S. C. Singhal and J. Mizusaki, Editors, PV 2005-07, p. 524, The Electrochemical Society Proceedings Series, Pennington, NJ (2005).

14. A. Hagen, R. Barford, P. V. Hendriksen, Y.-L. Liu, and S. Ramousse, Solid Oxide Fuel Cells IX, S. C. Singhal and J. Mizusaki, Editors, PV 2005-07, p. 503, The Electrochemical Society Proceedings Series, Pennington, NJ (2005). 